\title{
Residual Oil Cracking with Generation of Hydrogen (Part 4)

\author{
Proposal for a New Cracking Process with Desulfurization \\ of Iron Sulfide by Roasting
}

Teruo Suzuka*1), Yasushi Ishibashi*2), Susumu Yoshioka*3),
Hidetaka Ohse*4), Tadashi Murakami*2) and Hiromi Ozaki*1)

A sulfur-containing residual oil has been cracked in a fluidized bed of an iron-containing catalyst with hydrogen generation of $180 \mathrm{Nl}-\mathrm{H}_{2} / \mathrm{kg}$-feed oil by reaction of ferrous oxide with steam and of $30 \mathrm{Nl}-\mathrm{H}_{2} / \mathrm{kg}$-feed oil by dehydrogenation of the feed oil. The iron sulfide formed in the catalyst during partial oxidation of coke has been desulfurized by roasting with air in a fluidized bed roaster. The desulfurization reaction has been found to be fast enough to attain equilibrium during roasting. Based on these results, a new cracking process has been proposed. It consists of cracking sulfur-containing residual oil, generation of hydrogen, partial oxidation of coke on the catalyst, fixation of gaseous sulfur compounds in the catalyst, and roasting of the iron sulfide.

\section{Introduction}

When a sulfur-containing residual oil is cracked over a catalyst containing iron, the iron oxide in the catalyst is sulfided to iron sulfide as previously reported $^{1)}$. It is necessary that this iron sulfide be desulfurized for repeated use of the catalyst for cracking. One of the desulfurizing techniques is to treat the iron sulfide with steam ${ }^{1)}$ to remove the sulfur as hydrogen sulfide. Another technique is to roast the iron sulfide to remove the sulfur as sulfur dioxide.

We have made studies of the latter technique and have proposed a new residual oil cracking process.

\section{Experimental}

\subsection{Feedstock}

Vacuum residual oil was used as feedstock. The properties are shown in Table 1.

\subsection{Catalyst}

The properties and composition of the catalyst used are shown in Table 2 .

Received Sept. 11, 1982.

*1) Technical Research Center, Nippon Mining Co., Ltd. (3-17-35, Niizo-Minami, Toda-shi, Saitama 335)

*2) Mizushima Refinery, Nippon Mining Co., Ltd. (2-1, Ushiodori, Kurashiki-shi, Okayama 712)

*3) Hitachi Research Laboratory, Hitachi Ltd. (832-2, Horiguchi, Katsuta-shi, Ibaraki 312)

*4) Head office, Kashima Oil Co., Ltd. (3, Kioi-cho, Chiyoda-ku, Tokyo 102)
Table 1 Properties of Feedstock

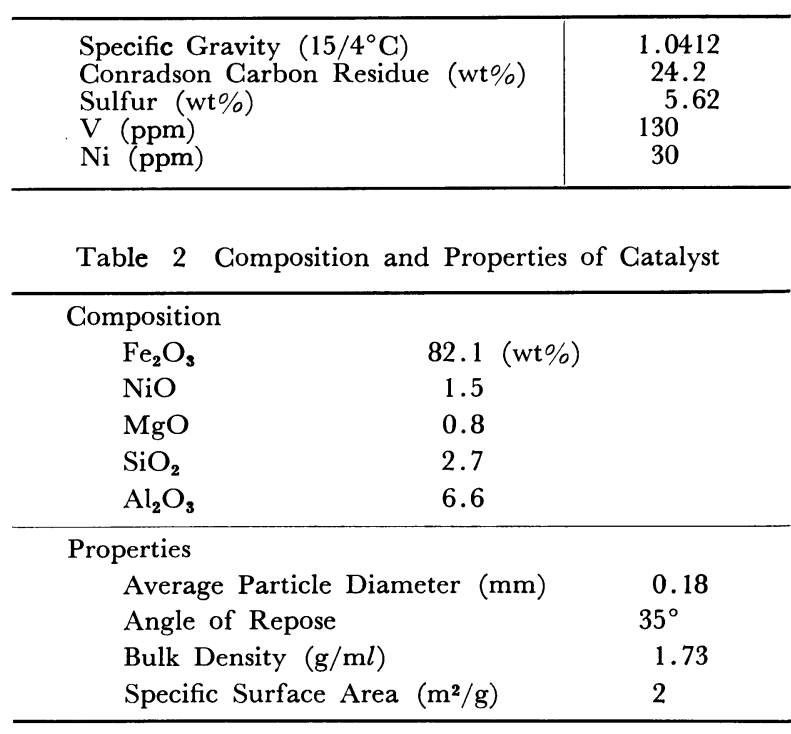

\subsection{Method of Experiment}

The experimental apparatus for cracking of residual oil with generation of hydrogen is shown in Fig. 1. Its feed capacity is $4 \mathrm{~kg} / \mathrm{hr}$. The three reactors (cracker, regenerator, and roaster) are made of type 304 stainless steel and heated with electric furnaces. Sizes of the reactors are shown in Table 3. The catalyst was circulated between cracker (1) and regenerator (2). The catalyst was continuously transferred from the regenerator (2) to the catalyst pot (6) with a rotary feeder (5) and it was periodically transferred to the catalyst hopper (7), from which the catalyst was supplied 


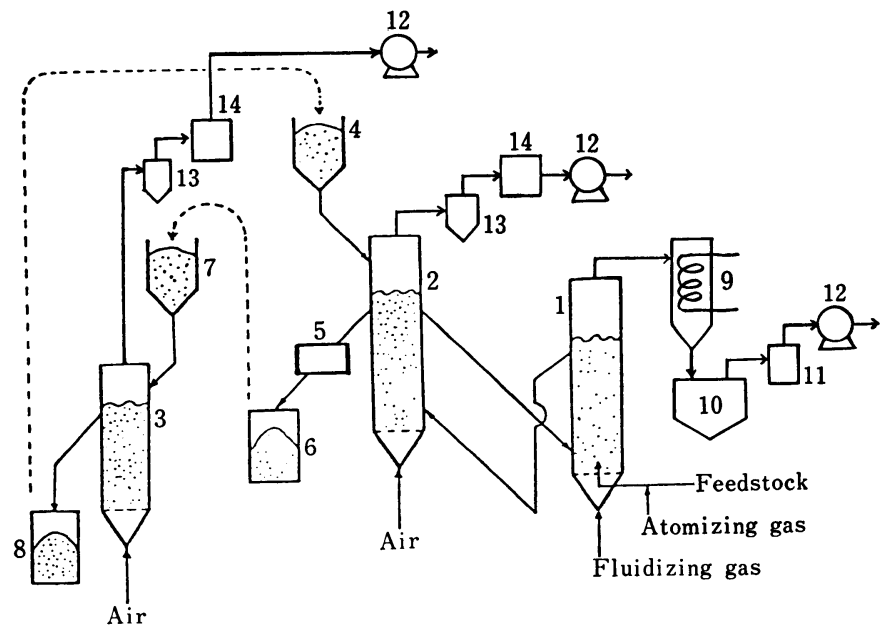

1. Cracker

2. Regenerator

3. Roaster

4. Catalyst hopper

5. Rotary feeder

6. Catalyst pot

7. Catalyst hopper

8. Catalyst pot

9. Quencher

10. Cracked oil trap

11. Filter

12. Gas meter

13. Cyclone

14. Cooler

Fig. 1 Flow Diagram of Experimental Apparatus

Table 3 Sizes and Operating Conditions of the Reactors

\begin{tabular}{|c|c|c|c|}
\hline & Cracker & Regenerator & Roaster \\
\hline $\begin{array}{l}\text { Sizes } \\
\text { Inner-diameter (mm) } \\
\text { Height (mm) } \\
\text { Height or Fluidized Bed (mm) }\end{array}$ & $\begin{array}{r}127 \\
1,600 \\
500\end{array}$ & $\begin{array}{r}151 \\
1,800 \\
500\end{array}$ & $\begin{array}{r}102 \\
1,900 \\
600\end{array}$ \\
\hline $\begin{array}{l}\text { Operating Conditions } \\
\text { Reaction Temperature }\left({ }^{\circ} \mathrm{C}\right) \\
\text { Fluidizing Gas } \\
\text { Superficial Velocity }(\mathrm{cm} / \mathrm{s}) \\
\text { Catalyst Circulation Rate }(\mathrm{kg} / \mathrm{hr}) \\
\text { Feed Rate of Vacuum Residual Oil }(\mathrm{kg} / \mathrm{hr}) \\
\text { Feed Rate of Steam }(\mathrm{kg} / \mathrm{hr}) \\
\text { Feed Rate of Air }\left(\mathrm{m}^{3} / \mathrm{hr}\right)\end{array}$ & $\begin{array}{c}525-545 \\
\text { steam or } \mathrm{N}_{2} \\
23-25 \\
\stackrel{4}{1.8-2.4} \\
1.2-3.0 \\
-\end{array}$ & $\begin{array}{l}780-830 \\
\text { air }+\mathrm{N}_{2} \\
36-40 \\
\longrightarrow \\
\longrightarrow \\
-5-2.0\end{array}$ & $\begin{array}{c}750-810 \\
\text { air }+\mathrm{N}_{2} \\
30-37 \\
- \\
- \\
2.0-2.6\end{array}$ \\
\hline
\end{tabular}

to the roaster (3). The catalyst discharged from the roaster (3) was accumulated in the catalyst pot (8) and transferred to the catalyst hopper (4) to supply the regenerator.

The residual oil was fed to the bottom of the cracker together with an atomizing and fluidizing gas. The cracked gas and oil were discharged from the cracker, and they were quenched in the quencher (9). The cracked gas was separated from the oil and water in the oil trap (10) and its flow rate was measured with the gas meter (12). Partial pressure of steam in the gas from the cracker was calculated from the amount of water separated.

The product gases from the regenerator and the roaster were cooled in the coolers (14), and their flow rates were measured with respective gas meters
(12). The composition of the gases was analyzed by gas chromatography. The operating conditions of the reactors are shown in Table 3 .

\subsection{Definition}

The excess air coefficient is expressed by the following equation:

$$
\text { Excess air coefficient }
$$

Amount of air fed to the roaster

$=$ Amount of combustion air theoretically required for the following reactions

$$
\begin{aligned}
& \mathrm{C}+\mathrm{O}_{2} \longrightarrow \mathrm{CO}_{2} \\
& \mathrm{~S}+\mathrm{O}_{2} \longrightarrow \mathrm{SO}_{2} \\
& 3 \mathrm{FeS}+5 \mathrm{O}_{2} \longrightarrow 3 \mathrm{SO}_{2}+\mathrm{Fe}_{3} \mathrm{O}_{4}
\end{aligned}
$$

\subsection{Analyses}

The amount of carbon deposited on the catalyst

\begin{tabular}{|c|c|c|c|}
\hline Gases & Gas Chromatograph & Packing & Detector \\
\hline $\begin{array}{l}\mathrm{Hydrocarbons} \\
\mathrm{CH}_{4}, \mathrm{H}_{2} \\
\mathrm{CO}_{2}, \mathrm{H}_{2} \mathrm{~S} \\
\mathrm{COS} \mathrm{H}_{2} \mathrm{~S}, \mathrm{SO}_{2} \\
\mathrm{CH}_{4}, \mathrm{CO}_{2} \\
\mathrm{~N}_{2}, \mathrm{H}_{2}, \mathrm{O}_{2}, \mathrm{CH}_{4}, \mathrm{CO}\end{array}$ & $\begin{array}{l}\text { HITACHI } 063 \\
\text { Shimadzu GC-2C } \\
\text { HITACHI K-23 } \\
\text { HITACHI 163 } \\
\text { Shimadzu 3BT } \\
\text { Shimadzu 3BT }\end{array}$ & $\begin{array}{l}\text { activated alumina TR } \\
\text { active carbon } \\
\text { Porapak } Q \\
\text { Porapak } Q \\
\text { active carbon } \\
\text { molecular sieve } 5 \mathrm{~A}\end{array}$ & $\begin{array}{l}\text { FID } \\
\text { TCD } \\
\text { TCD } \\
\text { FPD } \\
\text { TCD } \\
\text { TCD }\end{array}$ \\
\hline
\end{tabular}
was measured with a carbon analyzer (Kokusai Electric Co. "Coulomatic G"). The content of

Table 4 Analytical Conditions of Gas Chromatography 
sulfur in the coke-deposited catalyst was measured according to JIS K 2541.

The composition of product gases generated in the three reactors was analyzed by gas chromatography. Table 4 lists the analytical conditions.

The attrition resistance of the catalyst was determined by the method described in a previous paper $^{2}$.

\section{Results and Discussion}

\subsection{Cracking of Residual Oil}

Once-through cracking of the feed oil was conducted using steam as the atomizing and fluidizing gas. Typical yields of gas, oil, and coke obtained over the catalyst in the cracker are shown in

Table 5.

\subsection{Hydrogen Generation by Dehydrogena- tion of Residual Oil}

Cracking of residual oil was carried out using nitrogen instead of steam as the atomizing and fluidizing gas under the operating conditions shown in Table 3. The composition of the product gas is shown in Table 6. The amount of generated hydrogen was $29.4 \%$ of the product gas and 30 $\mathrm{Nl} / \mathrm{kg}$-feed oil. This hydrogen was apparently generated by dehydrogenation of the feed oil.

\subsection{Hydrogen Generation by Reaction of Ferrous Oxide with Steam}

The residual oil was cracked using steam as the atomizing and fluidizing gas under the operating conditions shown in Table 3. The composition of the product gas is shown in Table 6 . The amount of hydrogen generated was $69.4 \%$ by volume of the product gas and $210 \mathrm{Nl} / \mathrm{kg}$-feed oil. This hydrogen was apparently generated by both the reaction of ferrous oxide with steam and the dehydrogenation of residual oil. Steam reforming of hydrocarbons is not thought of as taking place at such a low cracking temperature ${ }^{3}$. Therefore, the difference between 210 and $30(=180 \mathrm{Nl} / \mathrm{kg}$ feed oil) must be the amount of hydrogen generated by the reaction of ferrous oxide with steam $\left(H_{\mathrm{S}}\right)$.

The coke-deposited catalyst was transferred from the cracker to the regenerator, and partial oxidation of coke was carried out at $800^{\circ} \mathrm{C}$. The triiron tetraoxide in the catalyst was simultaneously reduced to ferrous oxide. A typical composition of the gas from the regenerator is given in Table 7.

Figure 2 shows the relationship between $H_{\mathrm{S}}$ and $\mathrm{CO}_{2} / \mathrm{CO}$ molar ratio in the product gas from the regenerator. The lower the $\mathrm{CO}_{2} / \mathrm{CO}$ ratio was,
Table 5 Yields of Cracked Products

\begin{tabular}{c|c}
\hline Gas $(\mathrm{wt} \%)$ & 8 \\
Oil $(\mathrm{wt} \%)$ & 79 \\
$\mathrm{IBP}-180^{\circ} \mathrm{C}$ & 6 \\
$180-560^{\circ} \mathrm{C}$ & 30 \\
$560^{\circ} \mathrm{G}+$ & 43 \\
Coke $(\mathrm{wt} \%)$ & 14 \\
\hline
\end{tabular}

Table 6 Composition of Cracked Gas

\begin{tabular}{l|cc}
\hline \multicolumn{1}{c|}{ Fluidizing Gas } & $\mathrm{H}_{2} \mathrm{O}$ & $\mathrm{N}_{2}$ \\
\hline $\mathrm{H}_{2}($ vol $\%)$ & 69.4 & 29.4 \\
$\mathrm{CO}$ & 0 & 0 \\
$\mathrm{CO}_{2}$ & 1.2 & 0.2 \\
$\mathrm{H}_{2} \mathrm{~S}$ & 1.0 & 0.2 \\
$\mathrm{CH}_{4}$ & 11.7 & 27.0 \\
$\mathrm{C}_{2}$ hydrocarbons & 8.8 & 21.8 \\
$\mathrm{C}_{3}$ hydrocarbons & 5.4 & 13.1 \\
$\mathrm{C}_{4}$ hydrocarbons & 2.1 & 6.8 \\
$\mathrm{C}_{5}$ hydrocarbons & 0.4 & 1.5 \\
\hline $\mathrm{H}_{2} / \mathrm{CH}_{4}$ & 5.9 & 1.1 \\
$\mathrm{Hydrogen}$ Yield (Nl/kg-feed oil) & 210 & 30 \\
\hline
\end{tabular}

Table 7 Typical Composition of Gas from Regenerator

\begin{tabular}{l|c}
\hline $\mathrm{CO}$ & $16.8(\mathrm{vol} \%)$ \\
$\mathrm{CO}_{2}$ & 17.6 \\
$\mathrm{~N}_{2}$ & 61.5 \\
$\mathrm{CH}_{4}$ & 0.3 \\
$\mathrm{H}_{2}$ & 3.8 \\
$\mathrm{H}_{2} \mathrm{~S}$ & $47(\mathrm{ppm})$ \\
$\mathrm{COS}$ & $4(\mathrm{ppm})$ \\
$\mathrm{SO}_{2}$ & $134(\mathrm{ppm})$ \\
\hline
\end{tabular}

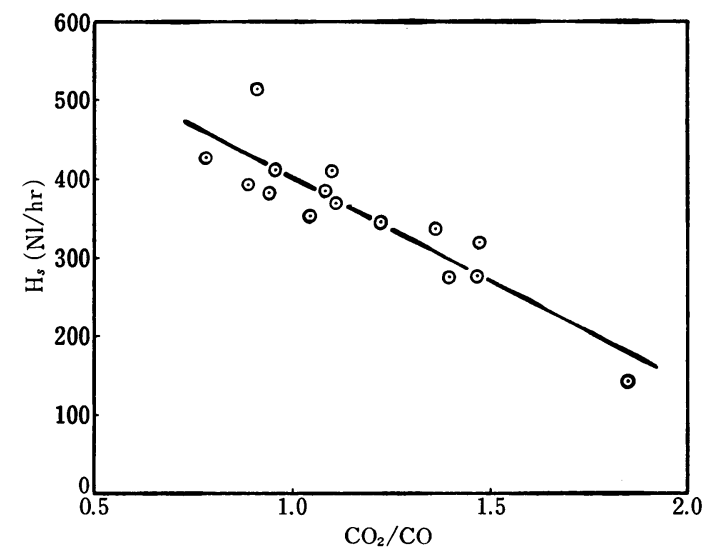

Fig. 2 Hydrogen Generated by Reaction of $\mathrm{H}_{2} \mathrm{O}$ with $\mathrm{FeO}$ in Cracker vs. $\mathrm{CO}_{2} / \mathrm{CO}$ Molar Ratio in the Product Gas from Regenerator

the higher the amount of hydrogen generated; that is, if the atmosphere inside the regenerator becomes more reducing, $H_{\mathrm{s}}$ increases, probably because the percent reduction of the catalyst increases. The decrease in the $\mathrm{O}_{2} / \mathrm{G}$ molar ratio produces a reducing atmosphere in the regenerator (wherein the $\mathrm{CO}_{2} / \mathrm{CO}$ ratio decreases), as shown in Fig. 3, resulting in an increase in $H_{\mathrm{S}}$.

Figure 4 shows the changes in the hydrogen 


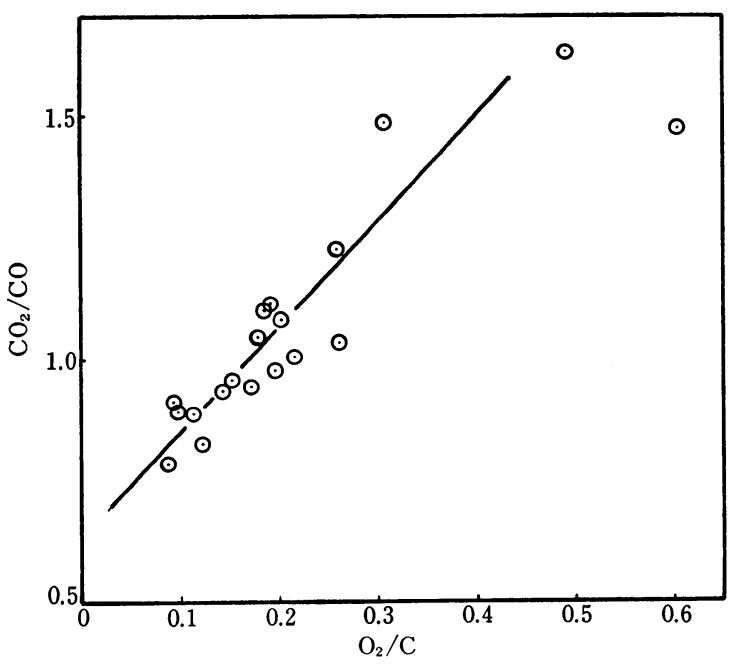

Fig. $3 \mathrm{CO}_{2} / \mathrm{CO}$ Molar Ratio in Product Gas from Regenerator vs. Molar Ratio of $\mathrm{O}_{2}$ in Air fed to Regenerator and $\mathrm{C}$ in Coke fed to Regenerator

concentration of the product gas from the cracker, the amount of hydrogen generated, and the $\mathrm{CO} /$ $\mathrm{CO}_{2}$ molar ratio in the product gas from the regenerator during a continuous ten-day-run. The amount of hydrogen generated is affected by partial pressure of steam. No catalyst deterioration is observed; the curve did fluctuate somewhat, however, due to the variation in the operating conditions. 3.4 Sulfur Distribution in Gracked Products

The sulfur distribution in the cracked products is shown in Table 8. The sulfur distributed to the coke and catalyst is oxidized to sulfur dioxide in the roaster, while the sulfur in the oil and gas is converted to hydrogen sulfide in the hydrodesulfurizer. Sulfur is recovered as molten sulfur
Table 8 Sulfur Distribution in Cracked Products

\begin{tabular}{l|r} 
Gas (wt \%) & 9 \\
Oil (wt \%) & 59 \\
Coke (wt \%) & 32 \\
Catalyst (wt \%) & \} \\
\hline Total & 100 \\
\hline
\end{tabular}

more easily from hydrogen sulfide than from sulfur dioxide. Therefore, the more sulfur distributed to gas and oil, the easier its recovery. Table 8 shows that fairly large amounts of sulfur are distributed to gas and oil.

Figure 5 shows the relationship between $\mathrm{H}_{2} \mathrm{~S} / \mathrm{H}_{2}$ and $\mathrm{H}_{2} \mathrm{O} / \mathrm{H}_{2}$ in the product gas from the cracker. It can be seen that partial pressure of hydrogen sulfide increases with increase in partial pressure of steam; that is, the sulfur distributed to the gas increases with increase in partial pressure of steam in the product gas. The relationship between $\mathrm{H}_{2} \mathrm{~S}$ / $\mathrm{H}_{2}$ and $\mathrm{H}_{2} \mathrm{O} / \mathrm{H}_{2}$ agrees well with the equilibrium line ${ }^{4)}$ obtained from the following equation: where

$$
\log \left(p_{\mathrm{H}_{2} \mathrm{O}} / p_{\mathrm{H}_{2}}\right)=3 / 4 \log \left(p_{\mathrm{H}_{2} \mathrm{~S}} / p_{\mathrm{H}_{2}}\right)-1 / 4 \log K_{\mathrm{T}}
$$

$p_{\mathrm{H}_{2} \mathrm{O}}, p_{\mathrm{H}_{2}}, p_{\mathrm{H}_{2} \mathrm{~S}}:$ partial pressures of $\mathrm{H}_{2} \mathrm{O}, \mathrm{H}_{2}$, and $\mathrm{H}_{2} \mathrm{~S}$, respectively

$K_{\mathrm{T}}$ : equilibrium constant of the reaction

$$
3 \mathrm{FeS}+4 \mathrm{H}_{2} \mathrm{O}=\mathrm{Fe}_{3} \mathrm{O}_{4}+3 \mathrm{H}_{2} \mathrm{~S}+\mathrm{H}_{2}
$$

\subsection{Desulfurization of $\mathrm{FeS}$}

Desulfurization of $\mathrm{FeS}$ was conducted under the operating conditions shown in Table 3. Percent combustion of carbon was compared with percent combustion of sulfur by varying the excess air coefficient at $750-810^{\circ} \mathrm{C}$. Figure 6 shows the relationship between excess air coefficient and percent combustion of carbon and percent combustion

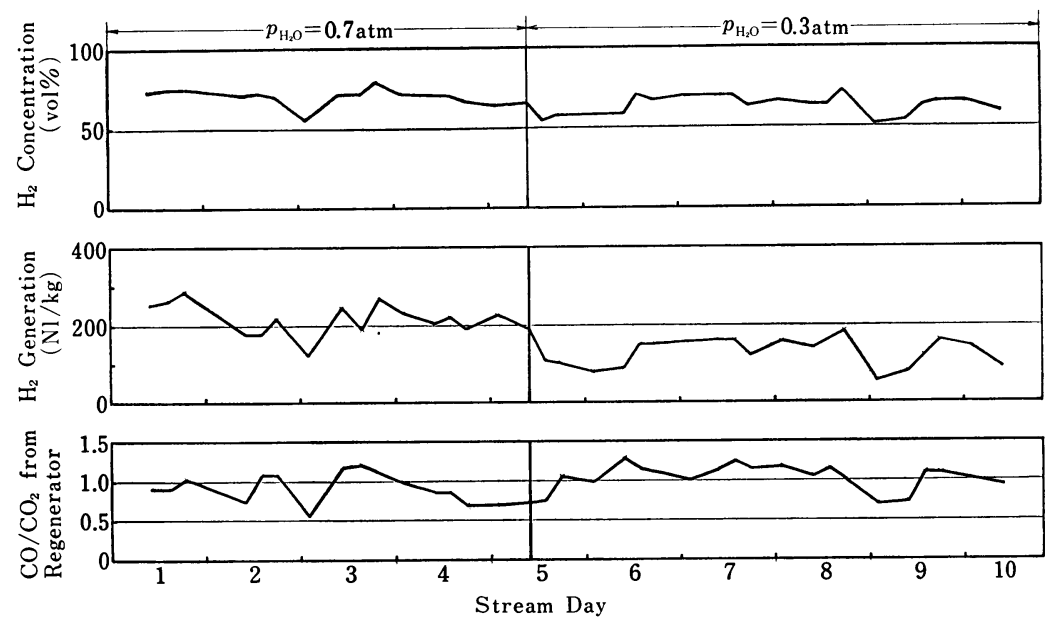

Fig. 4 Hydrogen Concentration in Product Gas from Cracker, Amount of Hydrogen Generated, and $\mathrm{CO} / \mathrm{CO}_{2}$ Molar Ratio in Product Gas from Regenerator during 10-Day-Run 


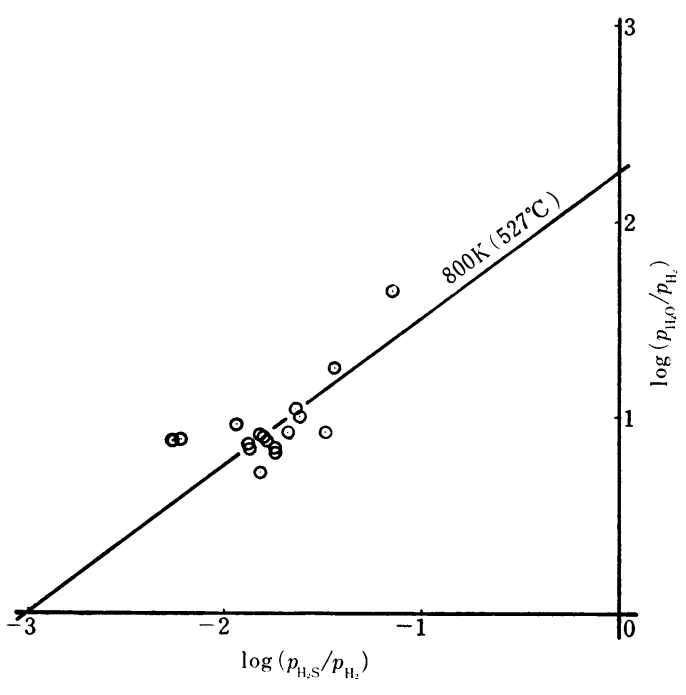

- equilibrium line obtained from

$\log \left(p_{\mathrm{H}_{2} \mathrm{O}} / p_{\mathrm{H}_{2}}\right)=3 / 4 \log \left(p_{\mathrm{H}_{2} \mathrm{~S}} / p_{\mathrm{H}_{2}}\right)-1 / 4 \log K_{\mathrm{T}}$

Fig. 5 Relationship between $\mathrm{H}_{2} \mathrm{~S}, \mathrm{H}_{2}$, and $\mathrm{H}_{2} \mathrm{O}$ in Product Gas from Cracker

of sulfur. It is found that sulfur is oxidized more easily than carbon, especially at low excess air coefficients.

Roasting of iron sulfide without coke is a wellknown process for sulfuric acid production ${ }^{5) \sim 8}$. In the present process, coke coexists with iron sulfide. It is preferable to minimize the consumption of coke during roasting because coke acts as an effective reductant of iron oxide.

Figure 7 shows the results of X-ray diffraction analyses of the catalyst before and after desulfurization. It can be seen in this figure that $\mathrm{FeS}$ is converted to $\mathrm{Fe}_{3} \mathrm{O}_{4}$ sufficiently and that the iron is not further oxidized beyond the $\mathrm{Fe}_{3} \mathrm{O}_{4}$ level.

Attrition resistance of the catalyst is plotted

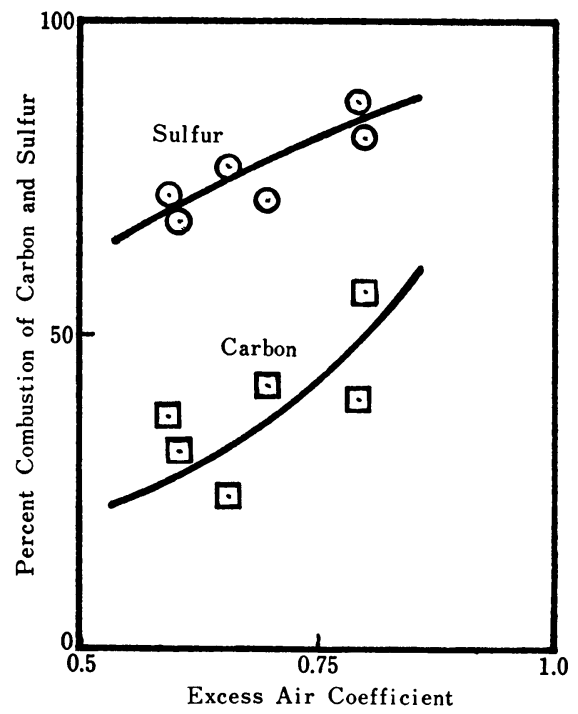

Sulfur content in catalyst fed to the roaster : $4.5-5.5 w t \%$

Carbon content in catalyst fed to the roaster : $2.2-4.5 \mathrm{wt} \%$

Reaction temperature : $750-810^{\circ} \mathrm{C}$

Fig. 6 Effect of Excess Air Coefficient on Percent Combustion of Carbon and Sulfur in Roaster

against process time in Fig. 8, which indicated that it did not change during the run.

Composition of the product gas from the roaster is compared in Table 9 with the equilibrium values calculated by Yazawa's method ${ }^{9}$. The good agreement between them indicates that desulfurization reaction is fast enough to attain equilibrium during roasting in the roaster.

\subsection{Gracking Process for Residual Oil of High Sulfur Content}

The above observations permit us to deduce the

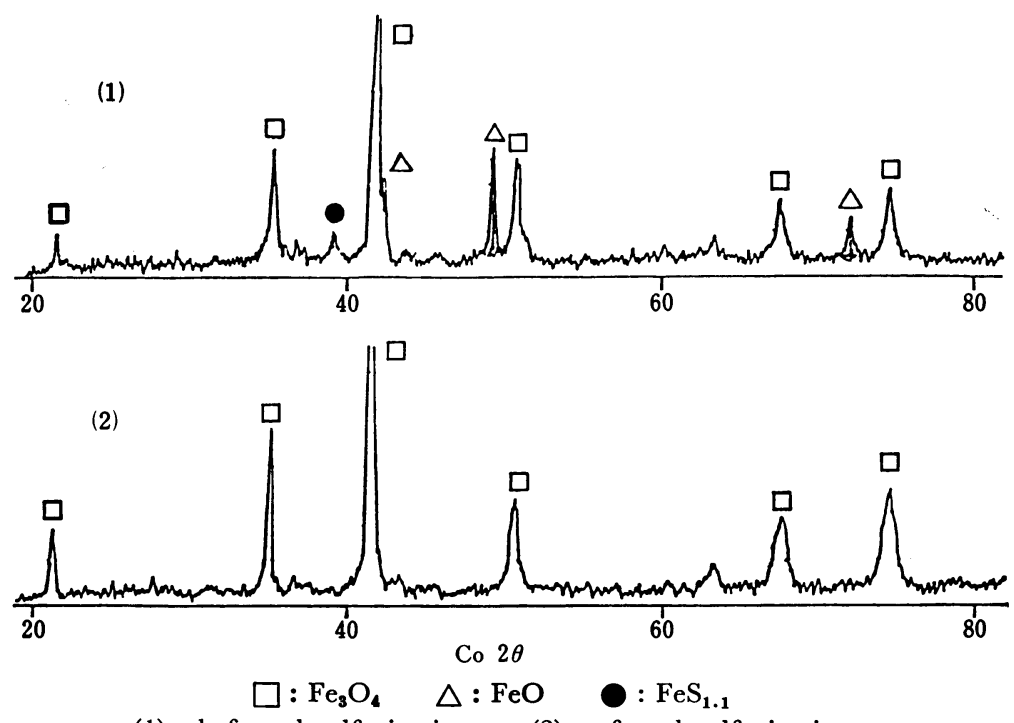

(1) before desulfurization (2) after desulfurization

Fig. 7 X-ray Diffraction Pattern of Catalyst before and after Desulfurization 


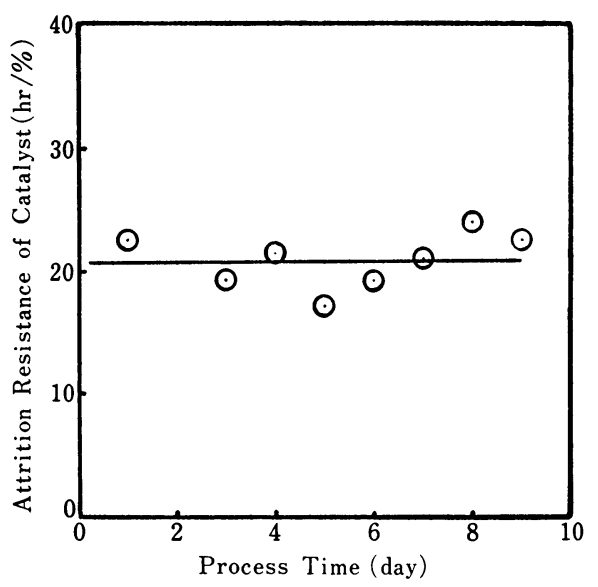

Fig. 8 Attrition Resistance of Catalyst vs. Process Time

Table 9 Composition of Gas from Roaster $\left(750^{\circ} \mathrm{C}\right)$

\begin{tabular}{l|cc}
\hline & Observed & Equilibrium \\
\hline $\mathrm{N}_{2}$ & 85.7 & 85.6 \\
$\mathrm{CO}_{2}$ & 5.2 & 4.3 \\
$\mathrm{SO}_{2}$ & 7.3 & 9.1 \\
$\mathrm{H}_{2} \mathrm{O}$ & 1.0 & 0.87 \\
$\mathrm{~S}_{2}$ & - & 0.17 \\
$\mathrm{H}_{2} \mathrm{~S}$ & trace & 0.010 \\
$\mathrm{CO}$ & 0 & 0.010 \\
$\mathrm{COS}$ & 0 & 0.002 \\
$\mathrm{H}_{2}$ & 0.05 & 0.002 \\
$\mathrm{O}_{2}$ & 0.67 & $10^{-14}$ \\
$\mathrm{CH}_{4}$ & 0 & $10^{-18}$ \\
\hline
\end{tabular}

following processes for residual oil cracking with generation of hydrogen.

(1) In the cracker, the vacuum residual oil is cracked over the catalyst containing iron oxide, and hydrogen is simultaneously generated by the reaction of ferrous oxide with steam.

Vacuum residual oil $\longrightarrow$ Gas + Oil + Coke
$3 \mathrm{FeO}+\mathrm{H}_{2} \mathrm{O} \longrightarrow \mathrm{Fe}_{3} \mathrm{O}_{4}+\mathrm{H}_{2}$

(2) In the regenerator, the coke deposited on the catalyst is partially oxidized, and triiron tetraoxide $\left(\mathrm{Fe}_{3} \mathrm{O}_{4}\right)$ is reduced to ferrous oxide $(\mathrm{FeO})$. The sulfur dioxide produced by partial oxidation of coke is fixed into the catalyst.

$$
\begin{aligned}
& \mathrm{Coke}+\mathrm{O}_{2} \longrightarrow \mathrm{CO}_{2}+\mathrm{SO}_{2}+\mathrm{H}_{2} \mathrm{O} \\
& \mathrm{CO}_{2}+\mathrm{C} \longrightarrow 2 \mathrm{CO} \\
& \mathrm{CO}+\mathrm{H}_{2} \mathrm{O} \longrightarrow \mathrm{CO}_{2}+\mathrm{H}_{2} \\
& \mathrm{Fe}_{3} \mathrm{O}_{4}+\mathrm{CO} \longrightarrow 3 \mathrm{FeO}+\mathrm{CO}_{2} \\
& \mathrm{SO}_{2}+3 \mathrm{H}_{2}+\mathrm{FeO} \longrightarrow \mathrm{FeS}+3 \mathrm{H}_{2} \mathrm{O} \\
& \mathrm{SO}_{2}+3 \mathrm{CO}+\mathrm{FeO} \longrightarrow \mathrm{FeS}+3 \mathrm{CO}_{2}
\end{aligned}
$$

(3) In the roaster, the sulfur fixed in the catalyst is desulfurized by roasting with air.

$$
\begin{aligned}
& 3 \mathrm{FeS}+5 \mathrm{O}_{2} \longrightarrow \mathrm{Fe}_{3} \mathrm{O}_{4}+3 \mathrm{SO}_{2} \\
& \mathrm{Coke}+\mathrm{O}_{2} \longrightarrow \mathrm{CO}_{2}+\mathrm{SO}_{2}+\mathrm{H}_{2} \mathrm{O}
\end{aligned}
$$

\section{Conclusion}

A sulfur-containing residual oil has been cracked in a fluidized bed of a catalyst containing iron. The iron sulfide formed in the catalyst during partial oxidation of coke has been desulfurized by roasting with air. The results obtained are as follows:

1) The amount of hydrogen generated was 30 $\mathrm{Nl} / \mathrm{kg}$-feed oil during the cracking of residual oil using nitrogen as the atomizing and fluidizing gas, however, it was $210 \mathrm{Nl} / \mathrm{kg}$-feed oil when steam was used as the atomizing and fluidizing gas. The difference is the amount of hydrogen generated by the reaction of ferrous oxide with steam.

2) It can be seen that partial pressure of hydrogen sulfide in the product gas from the cracker increases with increase in the partial pressure of steam. The relationship between $\mathrm{H}_{2} \mathrm{~S} / \mathrm{H}_{2}$ and $\mathrm{H}_{2} \mathrm{O} / \mathrm{H}_{2}$ agrees well with the equilibrium line obtained from the following equation:

$$
\begin{aligned}
\log \left(p_{\mathrm{H}_{2} \mathrm{O}} / p_{\mathrm{H}_{2}}\right) & =3 / 4 \log \left(p_{\mathrm{H}_{2} \mathrm{~S}} / p_{\mathrm{H}_{2}}\right)-1 / 4 \log K_{\mathrm{T}} \\
\left(3 \mathrm{FeS}+4 \mathrm{H}_{2} \mathrm{O}\right. & \left.=\mathrm{Fe}_{3} \mathrm{O}_{4}+3 \mathrm{H}_{2} \mathrm{~S}+\mathrm{H}_{2}\right)
\end{aligned}
$$

3) It has been found that sulfur is oxidized more readily than carbon, especially at low excess air coefficients. The desulfurization reaction is fast enough to attain equilibrium during roasting in the roaster.

4) The above observations permit us to deduce the following processes for residual oil cracking with generation of hydrogen:

In the cracker, the vacuum residual oil is cracked over the catalyst containing iron oxide, and hydrogen is simultaneously generated by the reaction of ferrous oxide with steam.

In the regenerator, the coke deposited on the catalyst is partially oxidized, and triiron tetraoxide is reduced to ferrous oxide. The sulfur dioxide produced by partial oxidation of coke is fixed in the catalyst.

In the roaster, the sulfur fixed in the catalyst is desulfurized by roasting with air.

\section{Acknowledgments}

The authors are grateful to Research Association for Residual Oil Processing for the financial support.

\section{References}

1) Suzuka, T., Inoue, Y., Aizawa, S., Ozaki, H., J. Japan Petrol. Inst., 26, (3), 174 (1983).

2) Suzuka, T., Ozaki, H., J. Japan Petrol. Inst., 25, (4), 228 (1982).

3) Takemura, Y., Morita, Y., Yamamoto, K., Kogyo Kagaku Zasshi, 68, (12), 2379 (1965) ; Morita, Y., Yamamoto, K., Kogyo Kagaku Zasshi, 64, (2), 291 (1961).

4) Suzuka, T., Inoue, Y., Aizawa, S., Ozaki, H., J. Japan 
Petrol. Inst., 26, (3), 181 (1983).

5) McGormick, S., Dayanada, M. A., Grace, R. E., Metallurgical Transactions B, 6B, 55 (1975).

6) Yazawa, A., Sulfuric Acid and Industry, 23, (10), 277 (1970).

7) Yagi, S., Kunii, D., Kogyo Kagaku Zasshi, 66, 133
(1953).

8) Hisajima, I., Kondo, Y., J. Mining and Metallurgical Inst. Japan, 68, 319 (1952).

9) Yazawa, A., Ohkura, T., Sulfuric Acid and Industry, 32, (11), 243 (1979).

\title{
要旨
}

\section{水素発生を伴う重質油分解 (第 4 報) 焙焼による硫化鉄の脱硫を含む新しい分解プロセスの提案}

\author{
鈴鹿 輝男 ${ }^{* 1)}$, 石橋 泰*2), 吉岡 進 ${ }^{* 3)}$, \\ 大瀬 秀隆 ${ }^{* 4)}$, 村上 正*2), 尾崎 博已*1)
}

硫黄分の多い重質油を鉄含有触媒上で分解すると，触媒中に 硫化鉄が蓄積することは前報1),2）で報告した。ここでは硫化鉄 の脱硫手段として空気による焙焼を含む重質油分解プロセスに ついての検討結果を報告する。

分解塔の中では水素発生と重質油分解が主な反応であるが, 水素発生は重質油分解時に起こる脱水素反応似上るものと酸化 第一鉄とスチームの反応汇よるるのとが考觉られる。そこで, 流動化ガスの種類を変えて, それぞれの反応汇よる水素発生量 を求めたところ, Table 6 に見られるように, 脱水素反応に 上る水素発生量が $30 \mathrm{Nl} / \mathrm{kg}$ 一原料油, 酸化第一鉄とスチームの

*1) 日本鉱業株式会社中央研究所 (335 戸田市新曾南 3-17-35)

*2) 日本鉱業株式会社水島製油所（712 倉敷市潮通 2-1）

*3) 株式会社日立製作所日立研究所（312 勝田市堀口 832-2)

*4) 鹿島石油株式会社本社（102 東京都千代田区紀尾井町 3)
反応による水素発生量が $180 \mathrm{Nl} / \mathrm{kg}$-原料油と推定された。

再生塔に供給するコークと流動化空気の比 $\left(\mathrm{O}_{2} / \mathrm{C}\right)$ を変兄 ることにより再生塔内の雾囲気を Fig. 3 亿示すように制御し て, 再生塔出口ガス中の $\mathrm{CO}_{2} / \mathrm{CO}$ 比と分解塔に护酸化第 一鉄とスチームの反応汇基づく水素発生量の関係を求めたとこ ろ，Fig. 2 に見られるよらによい相関が得られた。 焙瑨塔では，Fig. 6 亿示すように硫化鉄は焙焼によって容 易に脱硫され，反応条件を選択することによってある程度コ一 クの燃焼を抑制することが可能であることが判明した。

これらの実験結果に基づいて, 含硫黄重質油の分解, 水素発 生, 触媒上コークの部分酸化, ガス状硫黄化合物の触媒への固 定，そして硫化鉄の焙焼から成る新しい分解プロセスを提案し た。

\section{Keywords}

Cracking, Hydrogen generation, Iron oxide, Iron sulfide, Residual oil, Roasting 